\title{
Indirect Complexometric Determination of Mercury(II) Using Guanidine Nitrate as a Selective Masking Agent
}

\author{
Ronald Aquin Nazareth, N. V. SReekumar, and B. NARAyana ${ }^{\dagger}$ \\ Department of Studies in Chemistry, Mangalore University, Mangalagangothri-574 199, India
}

(Received February 13, 2001; Accepted August 3, 2001)

The direct EDTA titration ${ }^{1}$ of mercury(II) exhibits poor selectivity, because of the co-titration of other metal ions. The usual practice is to determine the sum of mercury and associated cations, and then to decompose the Hg-EDTA complex selectively with masking agents, such as thiosemicarbazide ${ }^{2}$ or cysteine, ${ }^{3}$ and titrate the liberated EDTA. In these methods copper causes serious interference. Although Ueno suggested potassium iodide ${ }^{4}$ as a masking agent in an alkaline medium for determining mercury in the presence of copper, many other cations interfered. Thiosulfate ${ }^{5}$ has also been reported as a masking agent for mercury in an alkaline medium, but the effect of copper was not studied. Barcza and Kores ${ }^{6}$ used thiocyanate to mask mercury during the titration of bismuth at a $\mathrm{pH}$ of 1.0 . The mercury thiocyanate complex could then be decomposed with silver ions, and the liberated mercury was titrated with EDTA at pH 5.0 to 6.0 in the same solution. Singh described the determination of mercury in the presence of various cations with thiourea ${ }^{7}$ as a masking agent. In this method, a minimal excess of thiourea should be used. This restriction causes a problem in the analysis of samples of completely unknown composition. The selective determination of mercury using $\mathrm{N}$ allylthiourea ${ }^{8}$ as a masking agent requires heating to decompose the $\mathrm{Hg}$-EDTA complex; some precipitation of $\mathrm{HgS}$ is also obtained. The method of mercury determination by Gadiyar et al. ${ }^{9}$ using 4-amino-5-mercapto-3- $n$-propyl-1,2,4-triazole as a replacing agent is inconvenient because the masking agent requires a tedious and time-consuming preparation. Although 2-imidazollidinethione ${ }^{10}$ and hexahydropyrimidine-2-thione ${ }^{11}$ as replacing agents were found to be accurate and reliable, these reagents require tedious and time-consuming preparations. Also, they are not readily available. Even though 2mercaptoethanol ${ }^{12}$ was used as a good masking agent, it is unpleasant to use because of its smell; also, $\mathrm{Cu}$ (II) interfered with excess reagent. Although sulfite as a masking agent ${ }^{13}$ overcomes all these difficulties, a large excess of the reagent affects the $\mathrm{pH}$ of the solution. The use of acetylacetone ${ }^{14}$ and sodium nitrite ${ }^{15}$ as masking agents for the indirect determination of mercury(II) was found to be convenient. Ions like Pd(II), $\mathrm{Sn}(\mathrm{II})$ and $\mathrm{Cu}(\mathrm{II})$ do not interfere in this method. 1,10Phenanthroline $^{16}$ and DL-cystein ${ }^{17}$ were used as masking reagents for the determination of mercury(II). In these methods ions like $\mathrm{Cu}(\mathrm{II}), \mathrm{Pd}(\mathrm{II}), \mathrm{Tl}(\mathrm{III})$ interfere. Cysteamine hydrochloride is also used as a selective masking agent, ${ }^{18}$ but ions like $\mathrm{Tl}(\mathrm{III})$ and $\mathrm{Cu}(\mathrm{II})$ are found to interfere.

\footnotetext{
$\doteqdot$ To whom correspondence should be addressed

E-mail: nbadiaka@yahoo.co.uk
}

In the present investigation, guanidine nitrate was used for the selective and quantitative determination of mercury(II) in the $\mathrm{pH}$ range of 5.0 to 6.0

\section{Experimental}

\section{Reagents and solutions}

All of the reagents used were of analytical reagent grade or chemically pure grade. A mercury nitrate solution $(0.01 \mathrm{M})$ was prepared by dissolving a known amount of mercuric nitrate in distilled water and standardized by the ethylene diamine method. ${ }^{19}$ A zinc sulfate solution $(0.02 \mathrm{M})$ was prepared from an analytical reagent-grade sample, and was standardized by a quinaldate method. ${ }^{19}$ Verifications of the standard mercury(II) and zinc(II) solutions were done by comparing the results with standard reference materials supplied by National Institute of Standards and Technology (NIST) Gaithersburg, MD. Solutions of various metal ions were prepared by dissolving calculated amounts of the metal nitrate/sulfate in distilled water. An EDTA solution $(0.02 \mathrm{M})$ was prepared by dissolving the disodium salt of EDTA in distilled water. Xylenol Orange indicator was prepared by grinding $1 \mathrm{~g}$ of Xylenol Orange with $100 \mathrm{~g}$ of potassium nitrate crystals, and used as such. Guanidine nitrate was used as a 5\% solution in distilled water.

\section{Procedure}

To an aliquot of acidic solution containing 2.01 to $160 \mathrm{mg}$ of mercury(II), 5 to $50 \mathrm{ml}$ of EDTA solution was added and diluted to about 60 to $130 \mathrm{ml}$. About $0.03 \mathrm{~g}$ of Xylenol Orange indicator was added and the $\mathrm{pH}$ of the solution was adjusted to 5.0 to 6.0 using hexamine $(10 \pm 2 \mathrm{~g})$. Excess EDTA was titrated with a zinc sulfate solution. To this solution, 1 to $20 \mathrm{ml}$ of $5 \%$ guanidine nitrate solution was added and mixed well by shaking. The liberated EDTA was then titrated with a zinc sulfate solution. This second titer value corresponds to the mercury(II) present.

\section{Results and Discussion}

The absolute formation constant $(\log \beta)$ of $\mathrm{Hg}$-EDTA ${ }^{19}$ complex is 21.9 , yielding a log conditional stability constant of 15.3 at $\mathrm{pH}$ 5.0. Mercury(II) forms a stable soluble complex with guanidine nitrate as $\left[\mathrm{Hg}\left\{\mathrm{NH}_{2}-\mathrm{CH}(\mathrm{NH})-\mathrm{NH}_{2}\right\}_{2}\right]^{2+}$ with a $\log \beta$ value $^{20}$ of 24.96 . The sensitivity of this method is established by the effects of various quantities of $5 \%$ guanidine nitrate 


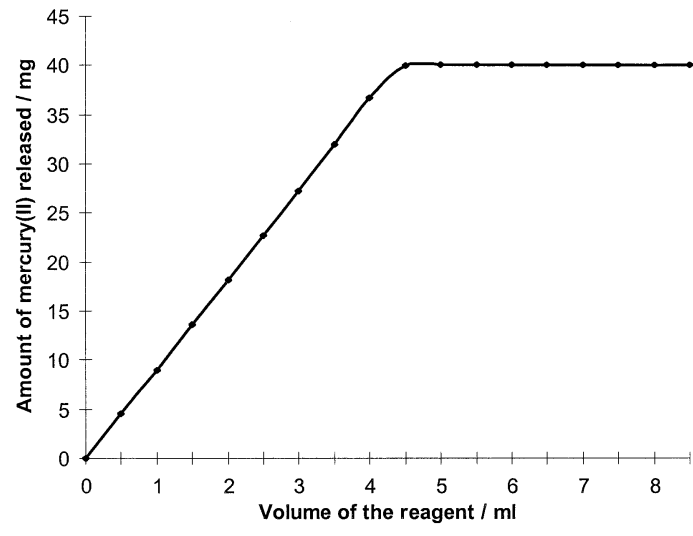

Fig. 1 Effect of 5\% guanidine nitrate solution used in the determination of mercury(II) $(40.12 \mathrm{mg})$.

Table 1 Determination of mercury(II) in mercuric nitrate solution

\begin{tabular}{rrrcc}
\hline $\begin{array}{c}\text { Mercury } \\
\text { present/mg }\end{array}$ & $\begin{array}{c}\text { Mercury } \\
\text { founda/mg }\end{array}$ & $\begin{array}{c}\text { Relative } \\
\text { error, \% }\end{array}$ & $\begin{array}{c}\text { Standard } \\
\text { deviation/mg }\end{array}$ & $\begin{array}{c}\text { Students' "t" } \\
\text { value }^{\mathrm{b}}\end{array}$ \\
\hline 2.01 & 2.01 & 0.00 & 0.01 & 0.00 \\
4.02 & 4.01 & -0.25 & 0.02 & 1.12 \\
8.02 & 8.03 & 0.12 & 0.03 & 0.75 \\
10.04 & 10.01 & -0.30 & 0.04 & 1.68 \\
20.59 & 20.56 & -0.15 & 0.07 & 0.96 \\
50.15 & 50.08 & -0.14 & 0.13 & 1.2 \\
100.29 & 100.17 & -0.12 & 0.26 & 1.03 \\
140.41 & 140.34 & -0.05 & 0.21 & 0.75 \\
160.47 & 160.30 & -0.11 & 0.22 & 1.73 \\
\hline
\end{tabular}

a. Average of five determinations.

b. Students" "t" test for $5 \%$ level of significance $=2.78$.

solution used for the recovery of $40.12 \mathrm{mg}$ of $\mathrm{Hg}$, as shown in Fig. 1. It is found that $1 \mathrm{ml}$ of $5 \%$ guanidine nitrate solution is required for each $9 \mathrm{mg}$ of mercury(II).

\section{Accuracy and precision}

The determinations of mercury in mercuric nitrate solutions were performed at different concentrations of mercury(II) using the above-mentioned reagents. The results are given in Table 1. It shows that the relative error did not exceed $\pm 0.30 \%$ and that the standard deviation is $\leq 0.26 \mathrm{mg}$. On comparing the computed value of students' " $\mathrm{t}$ " $(2.78$ for $5 \%$ level of significance) with the tabulated values, it can be observed that in most cases there is no significant difference between the reference values and the value obtained by the proposed method.

\section{Effect of foreign ions}

The effect of different cations and anions in the quantitative determination of $\mathrm{Hg}$ (II) was investigated at $40.12 \mathrm{mg}$ of $\mathrm{Hg}$ (II) in a solution using guanidine nitrate as a masking agent. There was no interference by the ions listed in Table 2. The reduction of $\mathrm{Au}(\mathrm{III})$ by EDTA and hydrolysis of $\mathrm{Sn}(\mathrm{IV})$ was avoided by using fluoride $\left(10 \% \mathrm{NH}_{4} \mathrm{~F} ; 20 \mathrm{ml}\right)$ for $10 \mathrm{mg}$ of $\mathrm{Au}(\mathrm{III})$ and 15 $\mathrm{mg}$ of $\mathrm{Sn}(\mathrm{IV})$.

\section{Applications}

Analysis of alloys of mercury(II). Mercury forms solid alloys with zinc and tin containing $42 \%$ and $15 \%$ mercury,
Table 2 Determination of mercury(II) in the presence of diverse ions $(40.12 \mathrm{mg})$

\begin{tabular}{|c|c|c|c|}
\hline Diverse ion & $\begin{array}{c}\text { Amount of } \\
\text { diverse ion/mg }\end{array}$ & $\begin{array}{l}\text { Mercury } \\
\text { found }{ }^{b} / \mathrm{mg}\end{array}$ & Relative error, $\%$ \\
\hline $\mathrm{Na}(\mathrm{I})$ & 275 & 40.10 & -0.05 \\
\hline $\operatorname{Ag}(\mathrm{I})$ & 50 & 40.17 & 0.12 \\
\hline $\mathrm{Zn}(\mathrm{II})$ & 100 & 40.10 & -0.05 \\
\hline $\mathrm{Co}(\mathrm{II})$ & 100 & 40.11 & -0.03 \\
\hline $\mathrm{Ni}(\mathrm{II})$ & 100 & 40.17 & 0.12 \\
\hline $\mathrm{Pb}(\mathrm{II})$ & 150 & 40.12 & 0.00 \\
\hline $\mathrm{Pd}(\mathrm{II})$ & 15 & 40.07 & -0.12 \\
\hline $\mathrm{Cu}(\mathrm{II})$ & 75 & 40.14 & 0.04 \\
\hline $\operatorname{Mn}(\mathrm{II})$ & 10 & 40.16 & 0.09 \\
\hline $\mathrm{Cd}(\mathrm{II})$ & 200 & 40.14 & 0.04 \\
\hline $\operatorname{Mg}(\mathrm{II})$ & 150 & 40.20 & 0.19 \\
\hline $\mathrm{Fe}(\mathrm{III})$ & 75 & 40.12 & 0.00 \\
\hline $\mathrm{Au}(\mathrm{III})^{\mathrm{a}}$ & 15 & 40.07 & -0.12 \\
\hline $\mathrm{Al}(\mathrm{III})$ & 125 & 40.07 & -0.12 \\
\hline $\mathrm{Bi}(\mathrm{III})$ & 100 & 40.12 & 0.00 \\
\hline $\mathrm{Ce}(\mathrm{III})$ & 50 & 40.16 & 0.09 \\
\hline $\mathrm{Cr}(\mathrm{III})$ & 50 & 40.17 & 0.12 \\
\hline $\mathrm{Tl}(\mathrm{III})$ & 100 & 40.10 & -0.05 \\
\hline V(IV) & 75 & 40.12 & 0.00 \\
\hline $\mathrm{Ti}(\mathrm{IV})$ & 100 & 40.20 & 0.19 \\
\hline $\mathrm{Pt}(\mathrm{IV})$ & 15 & 40.09 & -0.07 \\
\hline $\mathrm{Sn}(\mathrm{IV})^{\mathrm{a}}$ & 325 & 40.11 & -0.03 \\
\hline $\mathrm{U}(\mathrm{VI})$ & 100 & 40.16 & 0.09 \\
\hline $\mathrm{CH}_{3} \mathrm{COO}^{-}$ & 300 & 40.12 & 0.00 \\
\hline $\mathrm{NO}_{3}^{-}$ & 300 & 40.13 & 0.02 \\
\hline $\mathrm{Cl}^{-}$ & 15 & 40.11 & -0.03 \\
\hline $\mathrm{Br}^{-}$ & 30 & 40.10 & -0.05 \\
\hline $\mathrm{F}^{-}$ & 300 & 40.11 & -0.03 \\
\hline $\mathrm{SO}_{4}^{2-}$ & 350 & 40.12 & 0.00 \\
\hline $\mathrm{BO}_{3}{ }^{3-}$ & 400 & 40.14 & 0.04 \\
\hline $\mathrm{PO}_{4}{ }^{3-}$ & 300 & 40.12 & 0.00 \\
\hline
\end{tabular}

a. Masked using fluoride.

b. Average of five determinations.

Table 3 Determination of mercury in alloys

\begin{tabular}{ccccc}
\hline $\begin{array}{c}\text { Alloy } \\
\text { composition }\end{array}$ & $\begin{array}{c}\text { Expected } \\
\text { percentage of } \\
\text { mercury }\end{array}$ & $\begin{array}{c}\text { Mercury } \\
\text { found }^{\mathrm{a}}, \%\end{array}$ & $\begin{array}{c}\text { Relative } \\
\text { error, \% }\end{array}$ & $\begin{array}{c}\text { Standard } \\
\text { deviation, \% }\end{array}$ \\
\hline $\mathrm{Hg}+\mathrm{Zn}$ & 42.00 & 41.98 & -0.05 & 0.12 \\
$\mathrm{Hg}+\mathrm{Cu}$ & 83.49 & 83.47 & -0.02 & 0.09 \\
$\mathrm{Hg}+\mathrm{Mg}$ & 50.00 & 49.97 & -0.06 & 0.20 \\
$\mathrm{Hg}+\mathrm{Sn}{ }^{\mathrm{b}}$ & 15.00 & 15.04 & 0.27 & 0.12 \\
$\mathrm{Hg}+\mathrm{Na}$ & 67.70 & 67.71 & 0.01 & 0.11 \\
$\mathrm{Hg}+\mathrm{Mn}$ & 90.13 & 90.09 & -0.04 & 0.20 \\
$\mathrm{Hg}+\mathrm{Ni}$ & 93.19 & 93.24 & 0.05 & 0.14 \\
$\mathrm{Hg}+\mathrm{Pb}$ & 33.30 & 33.32 & 0.06 & 0.11 \\
$\mathrm{Hg}+\mathrm{Cd}$ & 37.00 & 37.19 & 0.51 & 0.45 \\
\hline
\end{tabular}

a. Average of five determinations.

b. Fluoride is used as secondary masking agent.

respectively. About $1.5 \mathrm{~g}$ to $3.0 \mathrm{~g}$ of accurately weighed pure alloy samples containing metals like $\mathrm{Zn}, \mathrm{Cu}, \mathrm{Mg}, \mathrm{Sn}, \mathrm{Na}, \mathrm{Mn}$, $\mathrm{Ni}$, and $\mathrm{Pb}$ were taken and heated with $5-10 \mathrm{ml}$ conc. nitric acid; the oxides of nitrogen were expelled by using of $0.5-1.0$ $\mathrm{ml}$ conc. sulfuric acid until the evolution of brown fumes ceased. The residue was extracted with distilled water and made up to $100 \mathrm{ml}$ in a standard flask. Aliquots of 5-10 ml were used for titration by the recommended procedure. The 
Table 4 Analysis of mercury(II) complexes

\begin{tabular}{lcccc}
\hline \multicolumn{1}{c}{ Complex } & $\begin{array}{c}\text { Mercury } \\
\text { present, \% }\end{array}$ & $\begin{array}{c}\text { Mercury } \\
\text { found }\end{array}$ & $\begin{array}{c}\text { Relative } \\
\text { error, \% }\end{array}$ & $\begin{array}{c}\text { Standard } \\
\text { deviation, \% }\end{array}$ \\
\hline $\mathrm{Hg}\left(\mathrm{C}_{3} \mathrm{H}_{6} \mathrm{~N}_{4} \mathrm{~S}\right)_{2}{ }^{\mathrm{a}}$ & 43.74 & 43.51 & -0.53 & 0.57 \\
$\mathrm{Hg}\left(\mathrm{C}_{3} \mathrm{H}_{6} \mathrm{~N}_{2} \mathrm{~S}_{2} \mathrm{Cl}_{2}{ }^{\mathrm{b}}\right.$ & 42.17 & 42.15 & -0.05 & 0.27 \\
$\mathrm{Hg}\left(\mathrm{C}_{4} \mathrm{H}_{8} \mathrm{~N}_{2} \mathrm{~S}_{2} \mathrm{Cl}_{2}{ }^{\mathrm{c}}\right.$ & 39.83 & 39.79 & -0.10 & 0.38 \\
$\mathrm{Hg}\left(\mathrm{C}_{10} \mathrm{H}_{11} \mathrm{~N}_{4} \mathrm{OS}\right)_{2}{ }^{\mathrm{d}}$ & 29.91 & 29.99 & 0.27 & 0.39 \\
$\mathrm{Hg}\left(\mathrm{C}_{9} \mathrm{H}_{7} \mathrm{~N}_{4} \mathrm{O}_{3}\right)_{2}{ }^{\mathrm{c}}$ & 31.41 & 31.66 & 0.80 & 0.32 \\
\hline
\end{tabular}

Mercury complexes of (a) 4-amino-5-mercapto-3-methyl-1,2,4triazole; (b) 2-imidazolidinethione; (c) hexahydropyrimidine-2thione; (d) 4-amino-5-mercapto-3-(o-tolyloxymethyl)-1,2,4-triazole; (e) 4-amino-3-mercapto-6-phenyl-1,2,4-triazin(4H)-5-one; (f) average of five determinations.

solution was analyzed for the concentration of $\mathrm{Hg}$ (II). The results are tabulated in Table 3.

Analysis of mercury(II) in complexes. A number of $\mathrm{Hg}(\mathrm{II})$ complexes with sulfur donor ligands ${ }^{21}$ were prepared by the conventional method, and their purity was checked by elemental analysis. About 0.1 to $0.2 \mathrm{~g}$ of the complex was decomposed by evaporation to near dryness with concentrated nitric acid and a few drops of conc. sulfuric acid. The residue was then cooled and dissolved in water, and made up to $100 \mathrm{ml}$ with water. Aliquots of $10 \mathrm{ml}$ were used for titration by the proposed method using guanidine nitrate as a masking agent. The results are tabulated in Table 4.

\section{Acknowledgements}

One of the authors (R. A. N.) thanks the University Grants Commission, New Delhi, India for awarding a fellowship under the Faculty Improvement Program.

\section{References}

1. T. S. West, "Complexometry with EDTA and related reagents", 1969, BDH, Poole.

2. J. Korbl and R. Pribil, Chem. Listy, 1957, 51, 667.

3. W. Berndt and J. Sara, Talanta, 1961, 8, 653.

4. K. Ueno, Anal. Chem., 1957, 29, 1669.

5. C. H. R. Nambiar, B. Narayana, B. Muralidhara Rao, B. Mathew, and B. Ramachandra, Microchem. J., 1996, 53, 175

6. L. Barcza and E. Koros, Chemist-Analyst, 1959, 48, 94.

7. R. P. Singh, Talanta, 1969, 16, 1447.

8. G. S. Vasilikiotis and C. D. Apostolopoulou, Microchem J., 1975, 120, 66.

9. H. R. A. Gadiyar, R. V. Gadag, and M. R. Gajendragad, Talanta, 1982, 29, 941.

10. B. Narayana and M. R. Gajendragad, Talanta, 1988, 35, 719.

11. B. Narayana, G. T. Kuchinad, and M. R. Gajendragad, Chinese J. Chem., 1992, 10, 394.

12. B. Muralidhara Rao and B. Narayana, Chim. Acta Turc., 1993, 21, 27.

13. B. Muralidhara Rao and B. Narayana, Mikrochim. Acta, 1993 III, 251.

14. B. Mathew, B. Muralidhara Rao, and B. Narayana, Analyst, 1995, 120, 1097.

15. B. Mathew, B. Muralidhara Rao, and B. Narayana, Mikrochim. Acta, 1995, 118, 197.

16. B. Ramachandra and B. Narayana, Ann. Chim., 1997, 87, 647.

17. A. Joseph and B. Narayana, Res. J. Chem. Environ., 1999, 3,49 .

18. A. Joseph, B. Narayana, and K. S. Bhat, J. Indian Chem. Soc., 1999, 76, 510.

19. A. I. Vogel, "A Textbook of Quantitative Inorganic Analysis", 3rd ed., 1968, Longman, London, 499, 533.

20. T. H. Wirth and N. Davidson, J. Am. Chem. Soc., 1964, 86, 4325.

21. A. Joseph, S. Mahadevi, and B. Narayana, Turkish J. Chem., 1994, 18, 14. 